\title{
The Effects of Olive Mill Wastewater on Soil Microbial Populations
}

\author{
Laith N. AL-Eitan ${ }^{1,2, *}$, Rami Q. Alkhatib ${ }^{1,2}$, Bayen S. Mahawreh ${ }^{1}$, Amneh H. Tarkhan ${ }^{1}$, Hanan I. Malkawi ${ }^{3}$, and Munir J. Rusan ${ }^{4}$ \\ ${ }^{1}$ Department of Applied Biological Sciences, Jordan University of Science and Technology, Irbid 22110, Jordan; ${ }^{2}$ Department of \\ Biotechnology and Genetic Engineering, Jordan University of Science and Technology, Irbid 22110, Jordan; ${ }^{3}$ Department of Biological \\ Sciences, Yarmouk University, Irbid 21163, Jordan; ${ }^{4}$ Department of Natural Resources and Environment, Jordan University of Science and \\ Technology, Irbid 22110, Jordan
}

Received: August 31, 2020; Revised: November 11, 2020; Accepted: November 24, 2020

\begin{abstract}
Olive mill wastewater (OMW) is a common pollutant in Jordan due to the large number of olive mills and the importance of the olive oil industry in the country. In this study, the effects of OMW and fertilizer on soil microbial populations were examined by counting the number of microbial colonies on each plate after respective treatments with water, OMW, and fertilizer. Colonies were identified based on macroscopic and microscopic examination as well as a range of biochemical tests. After treatment with OMW, a significant increase was exhibited in the Bacillus ( $p$-value of 0.011 in clay) and Yeast ( $p$ values of 0.001 in clay and 0.037 in sand) populations. In contrast, Staphylococcus, Streptomyces ( $p$-values of 0.034 in clay and 0.016 in sand) and Mold ( $p$-value of 0.013 in sand) exhibited population decreases. Our results showed that OMW significantly affects natural soil microbial populations, which is an important finding as most of the OMW in Jordan is disposed of in a way that exposes it to the soil. This study illustrated that OMW has a potential to be recycled and utilized as an antibacterial agent. Further studies should be conducted using molecular PCR analysis in order to accurately determine the species of each studied microorganism.
\end{abstract}

Keywords: olive mill wastewater; soil microbes; fertilizer; Jordan.

\section{Introduction}

Olive and olive oil production is of particular importance to the economic sectors of Jordan in particular and Mediterranean countries as a whole (Rusan et al., 2015). However, the olive oil industry generates a large amount of toxic drainage known as olive mill wastewater (OMW), the latter of which is characterized by an acidic $\mathrm{pH}$ as well as a high content of organic compounds and polyphenols (Ribeiro et al., 2018). The disposal of untreated OMW poses a number of threats to both environmental and public health, and its management is a source of considerable problems for most of the Mediterranean region (Ioannou-Ttofa et al., 2017). OMW has phytotoxic and inhibitory effects on plant growth, acts as an anti-bacterial agent, and contains compounds that are toxic to non-bacterial microorganisms, all of which result in an altered state of soil microbial diversity (Mekki et al., 2013; Ntougias et al., 2013; Rusan et al., 2016). Therefore, OMW can neither be disposed of directly into the environment nor into the sewage systems, and several different OMW management, treatment, and valorization strategies have been proposed (Souilem et al., 2017).

Jordan's eastern Mediterranean climate makes it particularly suited for the cultivation of olive trees, which hold great cultural, religious, and economic importance for the Jordanian people (Al Ganideh and Good, 2016). In fact, Jordan is a major exporter of olives and olive oil, and olive trees cover $73 \%$ of the agricultural land occupied by fruit trees (El Hanandeh and Gharaibeh, 2016). As a result, nearly 180,000 families are supported by the farming of 20 million olive trees, and the annual income from olive oil production is approximately 100 million Jordanian dinars (The Jordan Times, 2015). More than $70 \%$ of the Jordanian olive oil processing industry utilizes three-phase oil mills (86 out of a total of 118 oil mills as of 2011), while the remaining $30 \%$ consists of two-phase oil mills (20\%) and traditional press mills (10\%) (Qdais and Alshraideh, 2016). Three-phase oil mills produce large amounts of OMW, a pulp-like substance called olive cake, and a substantial amount of wastewater from washing the olives prior to extraction (Dourou et al., 2016).

Several studies have been conducted concerning OMW itself as well as its management and disposal in Jordan and abroad. OMW can be treated in jet-loop (JACTO) reactors in order to reduce its chemical oxygen demand (COD) and total phenol content by $85 \%$ and $80 \%$, respectively (Ribeiro et al., 2018; Khoufi et al., 2015). Furthermore, the simple act of diluting OMW with water was reported to eliminate its phytotoxic effects on plant growth (Rusan and Malkawi, 2016). In addition, biodegradation of OMW by various types of thermophilic bacteria is another potential treatment strategy that is under investigation (Al-Qodah et al., 2015). Moreover, volcanic tuff treated with nitric acid was found to reduce the COD and total phenol content of OMW by $14 \%$ and $21 \%$, respectively (Azzam, 2018). Likewise, natural Jordanian clay that was subject to calcination and acid treatment reduced the COD of OMW by up to 50\% (Azzam et al., 2015). Lastly, the use of OMW as a fertilizer was found to enhance plant growth, but such growth was lower than that obtained by

\footnotetext{
* Corresponding author e-mail: lneitan@just.edu.jo.
} 
conventional fertilizer and potable water (Rusan et al., 2015; Barbera et al., 2013).

Since OMW has been investigated in the context of plant growth and fertilization, it is important to also consider how OMW application might affect the microbial diversity of the soil it is being applied to. It has previously been found that olive washing conditions and the resulting OMW can affect the growth of certain fungal species in Jordan's environment (Massadeh et al., 2010; Al-Ameiri et al., 2015). Therefore, the main aim of this study is to investigate the impact of raw OMW on various soil microbiota obtained from local sources, specifically in comparison with fertilizer and water treatments.

\section{Materials and methods}

\subsection{Field and soil sampling}

Two types of soil samples were used in this study: clay and sand. Soil samples were collected from an on-campus site at Jordan University of Science and Technology, while raw OMW was collected from local olive mills in Irbid, Jordan. A greenhouse experiment was conducted to evaluate the effects of three treatments (tap water (W), tap water and fertilizer (W+F), and raw OMW) on the microbiota populations of clay and sand.

A total of 18 pots were filled with $5 \mathrm{~kg}$ of air-dried silty clay loam ( $\mathrm{n}=9)$ or $5 \mathrm{~kg}$ of air-dried sandy loam $(\mathrm{n}=9)$, so that each treatment was replicated three times in a randomized complete block design. Three corn seeds were planted in each pot, after which the soil moisture was brought up to the field capacity water content. The amount of water required to bring the sand to field capacity was $900 \mathrm{~cm}^{3}$, while the amount required for the clay was 1,500 $\mathrm{cm}^{3}$. Afterwards, all the pots were watered periodically to keep the soil moisture level at field capacity. Irrigation solution was added three times per week depending on the losses of soil moisture by evapotranspiration, the latter of which was determined by the periodic weighing of the pots. Pretreatment characteristics of the soil and irrigation solutions are summarized in Tables $\mathbf{1}$ and 2, respectively. After 8 weeks of growth, the plants were harvested, and representative soil samples were taken from each pot after thoroughly mixing the soil.

Table 1. Characteristics of soil samples.

\begin{tabular}{|c|c|c|c|}
\hline Parameters & Units & Sand & Clay \\
\hline $\mathrm{pH}^{*}$ & - & 7.8 & 8.18 \\
\hline Electrical conductivity* & $\mathrm{dS} / \mathrm{m}$ & 1.2 & 0.61 \\
\hline $\begin{array}{l}\text { Calcium carbonate } \\
\left(\mathrm{CaCO}_{3}\right)\end{array}$ & $\%$ & 27.1 & 15.3 \\
\hline $\begin{array}{l}\text { Cation exchange capacity } \\
\text { (CEC) }\end{array}$ & $\mathrm{cmol} / \mathrm{kg}$ & 24.1 & 34.3 \\
\hline Organic matter & $\%$ & 1.01 & 0.72 \\
\hline Texture Class & - & $\begin{array}{l}\text { Sandy } \\
\text { loam }\end{array}$ & $\begin{array}{l}\text { Silty clay } \\
\text { loam }\end{array}$ \\
\hline
\end{tabular}

*of $1: 1$ soil:water suspension
Table 2. Characteristics of irrigation water and olive mill wastewater (OMW).

\begin{tabular}{lllll}
\hline Parameters & Units & Water & $\begin{array}{l}\text { Raw } \\
\text { OMW }\end{array}$ & $\begin{array}{l}\text { Treated } \\
\text { OMW }\end{array}$ \\
\hline $\mathrm{pH}$ & - & 7.8 & 4.7 & 6.2 \\
$\begin{array}{l}\text { Electrical conductivity } \\
\begin{array}{l}\text { Total suspended solids } \\
\text { (TSS) }\end{array}\end{array}$ & 0.6 & 7.6 & 5.1 \\
$\begin{array}{l}\text { Total polyphenol } \\
\text { content }\end{array}$ & 10 & 1236 & - \\
\hline
\end{tabular}

\subsection{Treatment of soil}

Soil samples were sieved and dried, and $1 \mathrm{~g}$ of each sample was mixed with $99 \mathrm{~mL}$ of sterile distilled water and placed in a reciprocal shaker to be shaken for three hours at $120 \mathrm{rpm}$. Each sample was properly diluted, and $0.1 \mathrm{~mL}$ was inoculated on nutrient agar (for general bacteria, Bacillus spp, and Staphylococcus spp), oatmeal agar (for Streptomyces spp), malt extract agar (for yeast), and potato dextrose agar (for molds).

\subsection{Culturing of microorganisms}

Inoculated plates were placed in an incubator at $37^{\circ} \mathrm{C}$ for incubation. The general bacterial, Bacillus and Staphylococcus colonies were counted after an incubation period of 24 hours, while the Streptomyces, yeast and mold plates required 4 days of incubation before their colonies were counted. There were two types of colonies on the nutrient agar plate, and they were separated into two groups depending on their morphology (Table 3).

Table 3. Colony morphology, microscopic examination and biochemical tests.

\begin{tabular}{lll}
\hline Biochemical test & $\begin{array}{l}\text { Type 1 } \\
\text { (Staphylococcus) }\end{array}$ & $\begin{array}{l}\text { Type 2 } \\
\text { (Bacillus) }\end{array}$ \\
\hline Colony morphology & White, round & $\begin{array}{l}\text { Large, flat, white, } \\
\text { smooth, non-pigment } \\
\text { producer }\end{array}$ \\
Gram staining & Gram-positive & Gram-positive \\
Shape of cell & Cocci & Long rod \\
$\begin{array}{l}\text { Arrangement of } \\
\text { cells }\end{array}$ & In clusters & In chains \\
Endospore staining & Non-spore former & - \\
Catalase & -ve & - \\
Benzidine & -ve & - \\
Nitrate red & -ve & - \\
Motility & -ve & - \\
\hline
\end{tabular}

\subsection{Microbial parameters}

In this study, the main parameters were the colony counts, macroscopic and microscopic examination, and a series of biochemical tests.

\subsubsection{Colony counts}

The main parameter used for observing the effect of each treatment on soil microbial populations was the colony count, which was carried out via a Quebec colony counter. The colony count is a basic microbiological technique that attempts to quantify the amount of bacterial growth in terms of number of colonies. Therefore, this technique is useful in the present study as it provides a 
quantitative means of measuring the effects of the various treatments on each bacterial population.

\subsubsection{Macroscopic and microscopic examination}

As there were two types of colonies on the nutrient agar plates, further examination was necessary to identify each genus. Macroscopically, it was found that Type 1 (Staphylococcus) microorganisms had a white and round appearance, while Type 2 (Bacillus) microorganisms had a large, flat, white and smooth surface with no pigment production. Upon microscopic examination, Type 1 (Staphylococcus) microorganisms had a cocci shape and were arranged in clusters, while Type 2 (Bacillus) microorganisms appeared as long rods that were linked together to form chains.

\subsubsection{Biochemical tests}

Several biochemical tests were employed in order to further ascertain the identities of the microorganisms. The first biochemical test was the basic Gram stain procedure in order to determine whether the cell was Gram-positive or Gram-negative. Afterwards, a series of biochemical tests were applied to the Group 1 (Staphylococcus) microorganisms in order to fully confirm their identity. These included the catalase, benzidine, nitrate red, and motility tests.

\subsubsection{Statistical analysis}

The data was analyzed by one-way ANOVA using IBM SPSS. Levene's test was first applied in order to test homogeneity of variance, and the post-hoc tests consisted of Tukey's test (for equal variances) and Games-Howell test (for unequal variances). All statistical analyses were conducted using SPSS statistical package 19.0 (SPSS Corp., USA).

\section{Results}

The application of OMW resulted in an increase in the general bacterial count compared with the application of fertilizer. Bacillus populations were the highest after OMW application and increased substantially after treatment with OMW in both clay and sand. The lower population was observed in sand. Like Bacillus, yeast populations were highest after OMW application in both sand and clay. However, yeast populations were much higher in clay compared to sand. On the other hand, the Streptomyces, Staphylococcus, and mold populations were the lowest after OMW application, as they decreased substantially after treatment in both clay and sand. The lower populations were observed in sand (Figure 1).

Table 4 shows statistical comparisons between the different types of treatments. There was a significant effect of the treatments on Bacillus populations in clay [F $(2,6)$ $=10.388, \mathrm{p}=0.011]$. The Tukey post hoc test indicates that the mean for the OMW treatment $\left(\mathrm{M}=20.3 \times 10^{5}\right.$, SD $=75.2 \times 10^{5}$ ) differs significantly from the mean for no treatment $\left(\mathrm{M}=8 \times 10^{5}, \mathrm{SD}=2 \times 10^{5}\right)$. Moreover, the treatments also had a significant effect on Streptomyces populations in clay $[F(2,6)=6.288, p=0.034]$. The Tukey post hoc test indicates that the mean for the OMW treatment $\left(\mathrm{M}=36.7 \times 10^{5}, \mathrm{SD}=15.2 \times 10^{5}\right)$ differs significantly from the mean for the fertilizer treatment (M $=11.6 \times 10^{6}, \mathrm{SD}=2.1 \times 10^{6}$ ). A significant result was also observed for Streptomyces populations in sand $[\mathrm{F}(2,6)=$ 8.988, $\mathrm{p}=0.016]$.

There was a significant effect of the treatments on mold populations in sand $[F(2,6)=9.653, p=0.013]$. The Tukey post hoc test indicates that the mean for the OMW treatment $\left(\mathrm{M}=10 \times 10^{3}\right.$, SD $\left.=2 \times 10^{3}\right)$ differs significantly from the mean for the fertilizer treatment $(\mathrm{M}$ $\left.=50 \times 10^{3}, \mathrm{SD}=17.3 \times 10^{3}\right)$ and the no treatment $(\mathrm{M}=40$ $\mathrm{x} 10^{3}, \mathrm{SD}=10 \times 10^{3}$ ) groups. There was a significant effect of the treatments on yeast populations in clay [F (2, $6)=34.543, p=0.001]$. The Tukey post hoc test indicates that the mean for the OMW treatment $\left(\mathrm{M}=24 \times 10^{4}, \mathrm{SD}=\right.$ $5.57 \times 10^{4}$ ) differs significantly from the mean for the fertilizer treatment $\left(\mathrm{M}=50 \times 10^{3}\right.$, SD $\left.=17.3 \times 10^{3}\right)$ and the no treatment $\left(\mathrm{M}=30 \times 10^{3}, \mathrm{SD}=10 \times 10^{3}\right)$ groups. For yeast populations in sand, a significant effect was also shown $[F(2,6)=6.000, p=0.037]$. The Tukey post hoc test did not indicate which groups showed the significant difference.

Table 4: Statistical comparisons between microbiota in the two types of soil.

\begin{tabular}{|c|c|c|c|c|c|}
\hline & Type of soil & Mean Square & Sum of Squares & $\mathbf{F}$ & P-value \\
\hline \multirow{2}{*}{ Bacillus } & Clay & $1.754 \times 10^{12}$ & $3.509 \times 10^{12}$ & 10.388 & $0.011 *$ \\
\hline & Sand & $4.878 \times 10^{11}$ & $9.756 \times 10^{11}$ & 2.851 & 0.135 \\
\hline \multirow{2}{*}{ Staphylococcus } & Clay & $2.413 \times 10^{12}$ & $4.827 \times 10^{12}$ & 3.899 & 0.082 \\
\hline & Sand & $6.544 \times 10^{11}$ & $1.309 \times 10^{11}$ & 4.007 & 0.078 \\
\hline \multirow{2}{*}{ Streptomyces } & Clay & $5.782 \times 10^{13}$ & $1.156 \times 10^{14}$ & 6.288 & 0.034 * \\
\hline & Sand & $4.219 \times 10^{13}$ & $8.439 \times 10^{13}$ & 8.988 & $0.016 *$ \\
\hline \multirow{2}{*}{ Mold } & Clay & $25.2 \times 10^{7}$ & $50.5 \times 10^{7}$ & 1.857 & 0.236 \\
\hline & Sand & $13 \times 10^{8}$ & $26 \times 10^{8}$ & 9.653 & $0.013 *$ \\
\hline \multirow{2}{*}{ Yeast } & Clay & $40.3 \times 10^{9}$ & $80.6 \times 10^{9}$ & 34.543 & $0.001 *$ \\
\hline & Sand & $16 \times 10^{8}$ & $32 \times 10^{8}$ & 6.000 & $0.037 *$ \\
\hline
\end{tabular}

*significant at $\mathrm{p}<0.05$ at $2 \mathrm{df}$ 

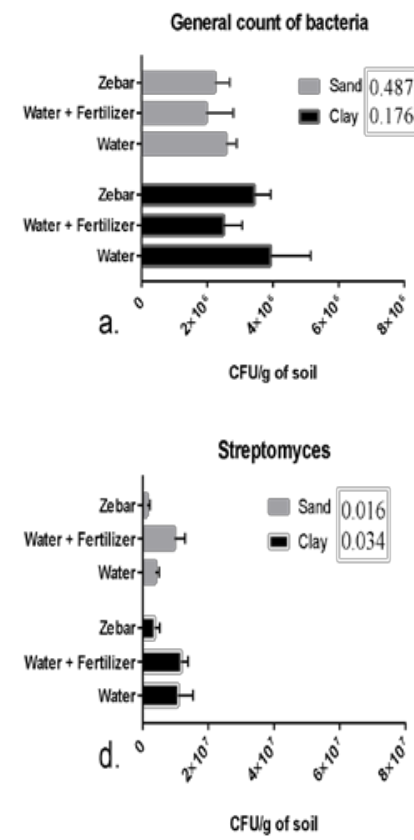

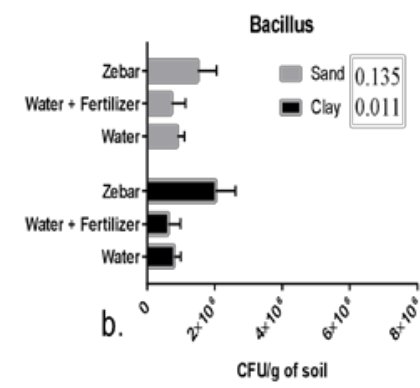

Molds

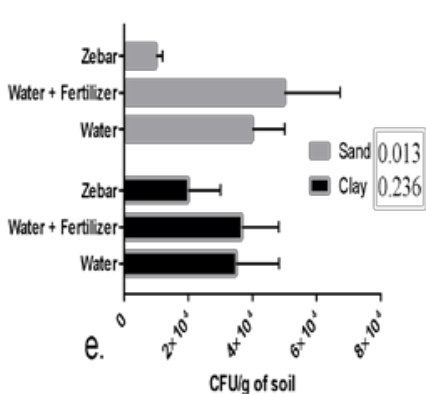

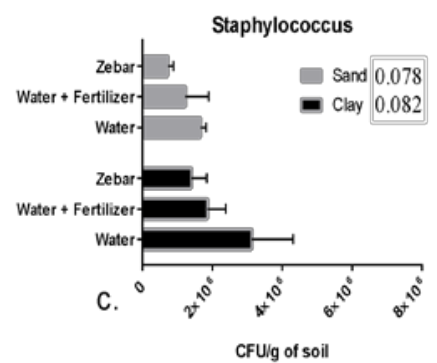

Yeast

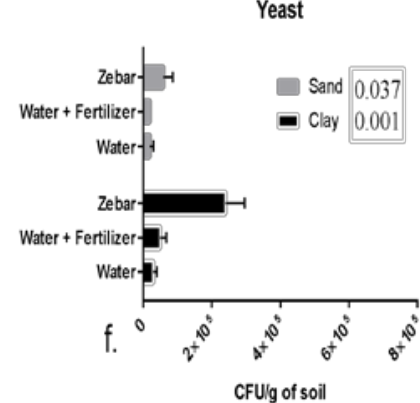

Figure 1: Graphical representation of colony counts (values in the legend represent the p-values): a. Applying raw OMW (zebar) resulted in an increase in the general count of bacteria in both sand and clay b. Bacillus populations exhibited increases in both sand and clay after application with OMW, with p-values of 0.135 and 0.011 , respectively c. while Staphylococcus populations decreased to almost half after OMW application, their p-values in sand (0.078) and clay (0.082) were not significant d. Streptomyces populations decreased substantially after OMW treatment, with p-values of 0.016 in sand and 0.034 in clay that were statistically significant e. Mold populations were also reduced after being treated with OMW, with p-values of 0.013 in sand and 0.236 in clay f. Yeast populations (like Bacillus) increased significantly after application of OMW, and the p-values in sand 0.037 and in clay 0.001 reflected this significance.

\section{Discussion}

The olive oil industry is predominant in Jordan and other Mediterranean countries, making the safe disposal of any waste and harmful by-products of the utmost environmental importance. As a consequence of the OMW's high phenolic composition, it has a significant antimicrobial effect on several types of native soil microorganisms. In Jordan, oil mills are prohibited from the direct disposal of OMW, and they cannot discharge the OMW into municipal wastewater treatment systems (Rusan et al., 2015). Instead, raw OMW is disposed of at specified dumping sites and their surrounding areas (Rusan and Malkawi, 2016). Therefore, the aim of the present study was to investigate the effects of raw OMW on native soil microbiota sourced from local sites.

The fact that OMW is generally detrimental to the microbial populations of soil was corroborated by the results obtained in this study, which showed that general bacterial populations decreased after exposure to raw OMW (Ntougias et al., 2013). Moreover, the application of OMW resulted in a major reduction of Staphylococcus and Streptomyces populations in both clay and sand, which agreed with previously published results (Tafesh et al., 2011). In contrast, the Bacillus population flourished in the presence of OMW, which could be explained by the fact that Streptomyces produces toxic substances that diminish Bacillus growth (de Lima Procópio et al., 2012). Correspondingly, one study reported that OMW sustained indigenous populations of Bacillus, while another found that OMW was conducive to Bacillus growth by protecting it from UV radiation (Yangui et al., 2008; Jallouli et al., 2014).

In terms of molds, our findings showed that the application of OMW led to an overall decrease in mold populations. Similarly, the application of OMW to fruit infected with gray mold as well as plum tree orchards led to a significant decrease in fungal formation (Saadi et al., 2007; Vagelas et al., 2009). Several types of molds, namely Alternaria, Colletotrichum, Sclerotium, and Rosellinia, species were strongly inhibited by the application of OMW (Cibelli et al., 2017). In contrast, the spreading of OMW to a field of olive trees led to an almost 5-fold increase in arbuscular mycorrhizal fungi, which caused the fungal-bacterial ratio to increase from 0.23 to 1.11 (Mechri et al., 2008). Concerning yeast, our findings show that yeast populations grew substantially when treated with OMW, with increases of $700 \%$ and $200 \%$ in clay and sand, respectively. Few studies about the effects of OMW on yeast were reported. However, the role of various yeast strains in the biodegradation of OMW phenols has been previously confirmed (Jarboui et al., 2012; Bevilacqua et al., 2013).

There are several limitations of the present study. Firstly, the populations of microorganisms were not measured before treatment, a step that is required to fully understand the anti-microbial effects of OMW. Secondly, representative soil sampling after plant harvest may have missed root-associated bacteria, i.e., rhizobacteria, which might also be affected by OMW.

In the present study, Jordanian OMW is suggested to unequally impact the growth of a variety of microorganisms depending on the type of soil. While Bacillus spp and yeast flourished under OMW treatment, Staphylococcus spp, Streptomyces spp, mold, and the general bacteria all exhibited decreases in colony counts. More research is needed to elucidate this difference in bacterial response, and future studies could further analyze OMW's antimicrobial effects in order to utilize it as a possible disinfectant. In addition, molecular PCR analysis could also be employed in order to determine the exact species of each microorganism that was studied. 


\section{Acknowledgements}

This work was prepared within the framework of the project titled "Mediterranean Cooperation in the Treatment and Valorisation of OMW (MEDOLICO)", which was funded by the European Union under the "ENPI CrossBorder Cooperation Mediterranean Sea Basin Programme" . The total budget for MEDOLICO was 1.9 million Euros, and it was co-financed by the European Neighborhood and Partnership Instrument $(90 \%)$ and the national funds of the countries participating in the project (10\%).

\section{References}

'Jordan among world's top 10 producers of olive, olive oil'. 2015. The Jordan Times. Available at: http://www.jordantimes.com/news/local/jordan-amongworld\%E2\%80\%99s-top-10-producers-olive-oliveoil\%E2\%80\%99 (Accessed: 9 August 2021).

Al Ganideh SF and Good LK. 2016. Nothing Tastes as Local: Jordanians' Perceptions of Buying Domestic Olive Oil. J Food Prod Mark., 22(2): 168-190.

Al-Ameiri NS, Karajeh MR and Qaraleh SY. 2015. Molds Associated with Olive Fruits Infested with Olive Fruit Fly (Bactrocera oleae) and their Effects on Oil Quality. Jordan J Biol Sci., 8(3): 217-220.

Al-Qodah Z, Al-Shannag M, Bani-Melhem K, Assirey E, Alananbeh K and Bouqellah N. 2015. Biodegradation of olive mills wastewater using thermophilic bacteria. Desalin Water Treat., 56(7): 1908-1917.

Azzam MOJ, Al-Gharabli SI and Al-Harahsheh MS. 2015. Olive mills wastewater treatment using local natural Jordanian clay. Desalin Water Treat., 53(3): 627-636.

Azzam MOJ. 2018. Olive mills wastewater treatment using mixed adsorbents of volcanic tuff, natural clay and charcoal. $J$ Environ Chem Eng., 6(2): 2126-2136.

Barbera AC, Maucieri C, Cavallaro V, Ioppolo A and Spagna G. 2013. Effects of spreading olive mill wastewater on soil properties and crops, a review. Agric Water Manag., 119: 43-53.

Bevilacqua A, Petruzzi L, Corbo MR and Sinigaglia M. 2013. Bioremediation of Olive Mill Wastewater by Yeasts - A Review of the Criteria for the Selection of Promising Strains. In: Patil YB and Rao P (Eds.), Applied Bioremediation - Active and Passive Approaches. InTechOpen, UK.

Cibelli F, Bevilacqua A, Raimondo ML, Campaniello D, Carlucci A, Ciccarone C, Sinigaglia M and Corbo MR. 2017. Evaluation of Fungal Growth on Olive-Mill Wastewaters Treated at High Temperature and by High-Pressure Homogenization. Front Microbiol., 8: 2515.

de Lima Procópio RE, da Silva IR, Martins MK, de Azevedo JL and de Araújo JM. 2012. Antibiotics produced by Streptomyces. Brazilian J Infect Dis., 16(5): 466-471.

Dourou M, Kancelista A, Juszczyk P, Sarris D, Bellou S, Triantaphyllidou IE, Rywinska A, Papanikolaou S and Aggelis G. 2016. Bioconversion of olive mill wastewater into high-added value products. J Clean Prod., 139: 957-969.

El Hanandeh A and Gharaibeh MA. 2016. Environmental efficiency of olive oil production by small and micro-scale farmers in northern Jordan: Life cycle assessment. Agric Syst., 148: $169-177$.

Ioannou-Ttofa L, Michael-Kordatou I, Fattas SC, Eusebio A, Ribeiro B, Rusan M, Amer ARB, Zuraiqi S, Waismand M, Linder C, Wiesman Z, Gilron J and Fatta-Kassinos D. 2017. Treatment efficiency and economic feasibility of biological oxidation, membrane filtration and separation processes, and advanced oxidation for the purification and valorization of olive mill wastewater. Water Res. 114: 1-13.
Jallouli W, Sellami S, Sellami M and Tounsi S. 2014. Efficacy of olive mill wastewater for protecting Bacillus thuringiensis formulation from UV radiations. Acta Trop., 140: 19-25.

Jarboui R, Baati H, Fetoui F, Gargouri A, Gharsallah N and Ammar E. 2012. Yeast performance in wastewater treatment: case study of Rhodotorula mucilaginosa. Environ Technol., 33(7-9): 951-960.

Khoufi S, Louhichi A and Sayadi S. 2015. Optimization of anaerobic co-digestion of olive mill wastewater and liquid poultry manure in batch condition and semi-continuous jet-loop reactor. Bioresour Technol., 182: 67-74.

Massadeh MI, Fraij A and Fandi K. 2010. Effect of Carbon Sources on the Extracellular Lignocellulolytic Enzymetic System of Pleurotus Sajor-Caju. Jordan J Biol Sci., 3(2): 51-54.

Mechri B, Ben Mariem F, Baham M, Ben Elhadj S and Hammami M. 2008. Change in soil properties and the soil microbial community following land spreading of olive mill wastewater affects olive trees key physiological parameters and the abundance of arbuscular mycorrhizal fungi. Soil Biol Biochem., 40(1): 152-161.

Mekki A, Dhouib A and Sayadi S. 2013. Review: Effects of olive mill wastewater application on soil properties and plants growth. Int J Recycl Org Waste Agric., 2(15): 1-7.

Ntougias S, Bourtzis K and Tsiamis G. 2013. The microbiology of olive mill wastes. Biomed Res Int., 2013: 784591.

Qdais HA and Alshraideh H. 2016. Selection of management option for solid waste from olive oil industry using the analytical hierarchy process. J Mater Cycles Waste Manag., 18: 177-185.

Ribeiro B, Torrado I, Di Berardino S, Paixão SM, Rusan MJ, Bani Amer A, Zuraiqi S and Eusébio A. 2018. Jet-loop reactor with cross-flow ultrafiltration membrane system for treatment of olive mill wastewater. Water Pract Technol. 13(2): 247-256.

Rusan MJM and Malkawi HI. 2016. Dilution of olive mill wastewater (OMW) eliminates its phytotoxicity and enhances plant growth and soil fertility. Desalin Water Treat., 57(57): 1-9. Rusan MJM, Albalasmeh AA and Malkawi HI. 2016. Treated Olive Mill Wastewater Effects on Soil Properties and Plant Growth. Water Air Soil Pollut., 227: 135.

Rusan MJM, Albalasmeh AA, Zuraiqi S and Bashabsheh M. 2015. Evaluation of phytotoxicity effect of olive mill wastewater treated by different technologies on seed germination of barley (Hordeum vulgare L.). Environ Sci Pollut Res., 22(12): 91279135.

Saadi I, Laor Y, Raviv M and Medina S. 2007. Land spreading of olive mill wastewater: Effects on soil microbial activity and potential phytotoxicity. Chemosphere, 66(1): 75-83.

Souilem S, El-Abbassi A, Kiai H, Hafidi A and Sayadi S. 2017. Olive oil production sector: environmental effects and sustainability challenges. In: Galanakis CM (Ed.), Olive Mill Waste. Academic Press, USA, pp. 1-28.

Tafesh A, Najami N, Jadoun J, Halahlih F, Riepl H and Azaizeh H. 2011. Synergistic antibacterial effects of polyphenolic compounds from olive mill wastewater. Evid Based Complement Alternat Med. 2011: 431021.

Vagelas I, Papachatzis A, Kalorizou H and Wogiatzi E. 2009. Biological Control of Botrytis Fruit Rot (Gray Mold) on Strawberry and Red Pepper Fruits by Olive Oil Mill Wastewater. Biotechnol Biotechnol Equip., 23(4): 1489-1491.

Yangui T, Rhouma A, Gargouri K, Triki MA and Bouzid J. 2008. Efficacy of olive mill waste water and its derivatives in the suppression of crown gall disease of bitter almond. Eur J Plant Pathol., 122: 495-504. 